\title{
A Republican Natural History in Spain around 1900: Odón de Buen (1863-1945) and His Audiences
}

\begin{abstract}
This paper discusses the political dimension of Odón de Buen's (1863-1945) expository practices_teaching and popularizing —as a university professor of natural history in Barcelona and later in Madrid at the turn of the nineteenth century. De Buen appropriated Ernst Haeckel's ideas on evolution in order to promote an ambitious political agenda, based on republican, freethinking, anticlerical values. To that end, he moved beyond the confines of academic science within the university and sought to bring modern concepts of natural history into elementary schools, athenaeums, political clubs and associations, scientific trips, popular books, periodicals, and the daily press. In such places, de Buen's natural history acted as an intellectual weapon with which to confront the conservative monarchic attitudes of the Spanish Restoration, but it also provided a moral backing to a society, which felt backward in terms of science and technology and was desperately seeking new sources of inspiration and national pride. KEY WORDS: natural history, Odón de Buen, Ernst Haeckel, science popularization, expository science, science and religion, Spain, republican science, Darwinism
\end{abstract}

\section{INTRODUCTION}

On October 9, I895, the newspaper La Vanguardia reported on a serious crisis that had occurred the previous day at the University of Barcelona. In an article entitled "Puñetazos y bofetadas" (Punches and Slaps), the conflict was described as follows:

*Centre d'Història de la Ciència (CEHIC), Facultat de Ciències, Universitat Autònoma de Barcelona, 08193 Cerdanyola del Vallès, Barcelona, Spain; agusti.nieto@uab.cat.

The following abbreviations are used: BEM, Boletin de la Escuela Moderna; CSIC, Consejo Superior de Investigaciones Científicas; EM, Escuela Moderna; IEO, Instituto Español de Oceanografîa; ILE, Institución Libre de Enseńaza; SEHN, Sociedad Espańola de Historia Natural; SFZ, Société française de zoologie.

Unless otherwise noted all translations from Spanish to English are the author's.

Historical Studies in the Natural Sciences, Vol. 42, Number 3, pps. 159-189. ISSN 1939-1811, electronic ISSN 1939-182X. (c) 2012 by the Regents of the University of California. All rights reserved. Please direct all requests for permission to photocopy or reproduce article content through the University of California Press's Rights and Permissions website, http://www.ucpressjournals.com/reprintinfo.asp. DOI: 10.1525/hsns.2012.42.3.159. 
As the students left Professor Casaña's [the rector's] office they broke into cries of: "You don't understand" and "Out!" Those students who were gathered at the entrance of the university responded with cries of "Long live the rector," "Long live Catholic Unity," and a fight broke out, with the area becoming a battlefield. The fight did not appear to be dissipating, and previously authorized police entered the university, splitting up the groups and clearing the students from the corridors and stairways.... In order to avoid further clashes Mr. de Buen left the university, offering his classroom to the persecuted students. However, the students could not use it since the porter locked the classroom door and kept the key. ${ }^{1}$

Six years earlier, in 1889 , at the Science Faculty of the University of Barcelona, Odón de Buen (1863-1945) had been appointed professor of natural history, and soon became responsible for courses in zoology, botany, and geology. In the early I890s, in his lectures and textbooks, he publicly admitted his commitment to evolutionary thought, which eventually caused Barcelona's bishop, Jaume Català, to take a stand against de Buen's teaching practices and subsequently to ban de Buen's manuals and cancel his courses. ${ }^{2}$ In the city, the affair soon became a serious matter, and news of it reached the central political authorities in Madrid. Students, university professors, intellectuals, and journalists argued strongly in support of de Buen and his right to academic freedom of expression (libertad de cátedra). After more than two months of public controversy, de Buen was finally allowed to resume his regular teaching activities at the university. It was a moral victory, but, as we will later observe, it left its mark on him for the rest of his life.

I. La Vanguardia, 9 Oct I895: "Al bajar los escolares de las habitaciones del señor Casańa prorrumpieron en gritos de: 'No lo entiende Vd.' Y de 'Fuera', a lo que oído por algunos de los reunidos en la entrada de la Universidad, contestaron con voces de 'Viva el Rector,' 'Viva la Unidad Católica,' comenzando entonces entre uno y otro bando una colisión, en la que se repartieron sendos mojicones, convirtiéndose aquel lugar en un campo de Agramante. La lucha entablada no llevaba trazas de terminar fácilmente, a no ser por la intervención de la policía, que previa autorización, penetró en la Universidad, despejando los grupos y alejando de los pasillos y las escaleras a los estudiantes... Para evitar nuevas manifestaciones el señor de Buen abandonó la Universidad, si bien antes había ofrecido su clase para que en ella se albergaran los estudiantes perseguidos. Su ofrecimiento no pudo tener efecto ya que el bedel cerró la puerta de la clase, guardando la llave.” [Anonymous], "Puñetazos y bofetadas."

2. Josep Arqués, Cinc estudis històrics sobre la Universitat de Barcelona (1875-1895) (Barcelona: Columna, 1985), 2I-66. See also Agustí Nieto-Galan, "El llibre de divulgació científica a la Barcelona de finals del segle XIX: autors, editorials, públics," in L'exaltació del llibre al Vuitcents: Art, indústria i consum a Barcelona, ed. Pilar Vélez (Barcelona: Biblioteca de Catalunya, 2008), 2OI-2O. 
The analysis of this conflict, and of the consequences of that turbulent public episode, inevitably demands an exploration of its root causes. As studied in depth by Thomas Glick some decades ago, the reception of evolutionary thought in Spain, and Darwin's work in particular, benefited largely from the atmosphere of freedom resulting from the 1868 liberal revolution. ${ }^{3}$ In tune with late-nineteenth-century secular reform movements, which continued beyond the brief period of liberty that ended with the restoration of the monarchy in 1874, the new regime abolished censorship, legalized academic freedom, and gave unprecedented support to experimental sciences. ${ }^{4}$ In the I870s, evolutionary thought spread in Spain among naturalists, and names such as Charles Darwin (I809-I882), Ernst Haeckel (I834-I919), and Herbert Spencer (I820I903) soon became preeminent in the public sphere. In 1876 , the astronomer Augusto Arcimis (1844-1910) translated John William Draper's History of the Conflict between Religion and Science into Spanish, with a preface by Nicolás Salmerón (I838-I908), a former president of the first Spanish Republic and a symbol of the spirit of $1868 .{ }^{5}$ French versions of Darwin's works circulated widely; in 1877 , the Cuban positivist José de Perojo (I850-1908) translated the Origin of Species into Spanish, and pro-Darwinist papers appeared in the Revista contemporánea, a journal that reflected the "regenerationist" ideas calling for a "scientific," "rational" reform of the country in view of its continuing decline on the world stage. 6

Anti-Darwinist papers and public lectures also began to spread, however. In the early I88os, anti-Darwin, but mainly anti-Haeckel, articles appeared regularly in journals such as El Sentido Católico de las Ciencias Médicas. Critical texts

3. See Thomas Glick, "Spain," in The Comparative Reception of Darwinism, ed. Thomas F. Glick (Austin: University of Texas Press, 1974), 307-45; Thomas F. Glick, Miguel Angel PuigSamper, and Rosaura Ruiz, eds., The Reception of Darwinism in the Iberian World: Spain, Spanish America and Brazil (Dordrecht, Neth.: Kluwer, 200I).

4. "Although the restoration (1874) re-established 'official science,' reintroduced religion into the university curriculum, and brought back censorship, and in spite of the fact that most of the Darwinists who had gained university science chairs in the wake of the revolution lost them during the [so-called] Second University Crisis of 1875 , the permeation of evolutionary ideas was so pervasive that Catholic revanchism was unable to roll back the tide." Glick, ed., Comparative Reception of Darwinism (ref. 3), 310.

5. John William Draper, Historia de los conflictos entre la religión y la ciencia (Madrid: Aribau y Cía, I876). On Arcimis, see Aitor Anduaga, "La regeneración de la astronomía y la meteorología españolas: Augusto Arcimis (I844-I9IO) y el institucionismo," Asclepio 58 (2005): I09-28.

6. Glick, "Spain" (ref. 3), 308-IO. For the scientific load of regenerationism, see Santos Casado, Naturaleza patria: Ciencia y sentimiento de la naturaleza en la España del regeneracionismo (Madrid: Marcial Pons, 2005). 
were written by, among others, Antonio Cánovas del Castillo (I828-I897), soon to become a conservative prime minister of the restored monarchy. ${ }^{7}$ Although moderate authors — some priests among them — attempted to find a balance between evolutionary thought and Christian dogma, de Buen was not the only naturalist to incur hostility from the Catholic Church in late-nineteenth-century Spain, nor the only pioneer in the use of popular texts and public lectures to spread evolutionary ideas. ${ }^{8}$ Moreover, public debates on Darwin and Haeckel were deeply influenced by political agendas. They became a significant battlefield in the continuous ideological clash between conservative forces and liberal movements, which reflected a Braudelian longue-durée phenomenon in different periods of Spanish history throughout the nineteenth century and lasting well into the twentieth century. ${ }^{9}$

Beyond Darwinism, Ernst Haeckel's ideal of conquering the public sphere with a new natural science that could potentially act as a powerful weapon on behalf of anticlericalism became a crucial republican value in Spain. ${ }^{10}$ Haeckel contributed to spreading a more scientifically grounded ethic, which openly competed with religion, especially in his popular books. Through his strong emphasis on the incompatibility between religious superstition and scientific reason, he seriously challenged the power of organized religion. ${ }^{11}$ In Robert Richards's words:

7. Thomas Glick, Darwin en España (Barcelona: Península, 1982), 92.

8. Rafael García (I828-I894) and Gregorio Chil (I83I-I9OI) were also prosecuted for their pro-Darwinist ideas. Francisco Pelayo, "Repercussion of Evolutionism in the Spanish Natural History Society," in Glick, Puig-Samper, and Ruiz, eds., Reception of Darwinism (ref. 3), 95-III; Glick, Comparative Reception of Darwinism (ref. 3).

9. Glick, Comparative Reception of Darwinism (ref. 3); José Alvarez Junco, Mater dolorosa: La idea de España en el siglo XIX (Madrid: Taurus, 200I).

Io. Álvaro Girón Sierra, Evolucionismo y anarquismo en España, I882-I9I4 (Madrid: CSIC, I996); Álvaro Girón Sierra, En la mesa con Darwin: Evolución y revolución en el movimiento obrero en España (I860-I9I4) (Madrid: CSIC, 2005).

II. On Haeckel as science popularizer, see Andreas W. Daum, Wissenschaftspopularisierung im I9 Jahrhundert: Bürgerliche Kultur, naturwissentschaftliche Bildung und die deutsche Öffentlichkeit, I848-I9I4 (Munich: R. Oldenburg, I998); Andreas W. Daum, "Varieties of Popular Science and the Transformations of Public Knowledge: Some Historical Reflections," Isis I00 (2009): 319-32. On Haeckel's life and works, see Robert J. Richards, The Tragic Sense of Life: Ernst Haeckel and the Struggle over Evolutionary Thought (Chicago: University of Chicago Press, 2008); Nick Hopwood, "Pictures of Evolution and Charges of Fraud: Ernst Haeckel's Embryological Illustrations," Isis 97 (2006): 260-30I; Paul Weindling, "Ernst Haeckel: Darwinism and the Secularization of Nature," in History, Humanism and Evolution: Essays for John C. Greene, ed. J. R. Moore (Cambridge: Cambridge University Press, I889), 3II-27. On Haeckel in Spain, see Francisco Pelayo, Ciencia y creencia en España durante el siglo XIX (Madrid: Universidad Complutense, I988). 
At every turn, [Haeckel] spiked the tentacles of organized religion, which he saw slithering up from Rome and out of the Church of northern Germany, threatening to strangle empirical science and liberal government. He preached the sheer incompatibility of religious superstition and scientific reason. The public conflict between science and religion ... can be attributed in large measure to the volcanic impact of Haeckel. ${ }^{12}$

Haeckel's monistic philosophy and his mechanical, empirical explanations strongly opposed supernatural, metaphysical forces. His departure from the old taxonomical, functional aspects toward a new living organism as an agent of adaptation, progress, and change fit well with several of de Buen's political extrapolations from natural laws to progress in society. ${ }^{13}$ Analogies between ontogeny and phylogeny suggested the possibility of an evolutionary progress toward a more advanced nature and a more advanced society, in which republican groups felt ideologically comfortable. Since in Haeckel's monism, human embryos all seem to be similar regardless of social origin, and even look similar to other mammal species in their early stages, there was no natural reason supporting the idea of inherited privilege. ${ }^{14}$

Although Haeckel's Darwinism has stirred a great variety of interpretations-Peter Bowler, for instance, asserts that Haeckel's biogenetic law illustrates the non-Darwinian character of his evolutionary thought - the fact is that his public impact was enormous. ${ }^{15}$ Haeckel's famous Natürliche Schöpfungsgeschichte [The History of Creation] was first published in German in I868, the year of the liberal Spanish revolution, and went through nine editions and was translated into twenty-five languages before World War I. In 1899, Haeckel had already sold more than ten thousand copies of his Die Welträthsel [The Riddle of the Universe]; the second edition, eventually translated into twelve languages, reached a hundred thousand copies. His subsequent book, Die Lebenswunder (1904) [Wonder of Life], was a response to critics of his monistic philosophy in The Riddle of the Universe, and a reaction to the more than five

I2. Robert Richards, "Biology," in From Natural Philosophy to the Sciences: Writing the History of Nineteenth-Century Science, ed. David Cahan (Chicago: University of Chicago Press, 2003), I6-48, on 27.

13. José Sala Catalá, Ideología y Ciencia biológica en España entre I860 y I88I: La difusión de un paradigma (Madrid: CSIC, 1987), I8.

I4. Diane B. Paul, "Darwin, Social Darwinism and Eugenics," in The Cambridge Companion to Darwin, ed. J. Hodge and G. Radick (Cambridge: Cambridge University Press, 2003), 214-39, on 232.

I5. Peter J. Bowler, Evolution: The History of an Idea (Berkeley: University of California Press, 1984). 
thousand letters he received from his readers. ${ }^{16}$ With regard to Spain, in the I880s Haeckel's main works were translated into Spanish in freethinking, masonic circles. ${ }^{17}$ In Valencia, for instance, the publisher Francisco Sempere undertook the translation of Haeckel's Las maravillas de la vida, Los enigmas del Universo, and Historia de la creación de los seres según las leyes naturales, all of which enjoyed considerable readership. ${ }^{18}$

These controversial appropriations of evolutionary thought coincided with Spain's continuing decline as a world power. Spanish science had almost no impact internationally. ${ }^{19}$ In 1898 , the loss of Cuba and the Philippines as a consequence of the war against the United States symbolized the last days of the Old Spanish Empire, and the whole country was engaged in intense selfcriticism, seeking out the causes of the military defeat. Public debates reflected a negative discourse in which, for a variety of reasons, the country's scientific capacity was called into question. ${ }^{20}$ In an atmosphere of national pessimism, evolutionary thought was used to explain Spain's decline in terms of its own struggle for survival in the fierce competition among nations. Among I868 republican circles, whose influence became marginalized nearly to the point of exclusion from the new elites of the restored monarchy after 1874, the defeat could be attributed to a degeneration process, in which conservative elites were largely responsible for the obstruction of scientific progress. ${ }^{21}$ In order to combat that degeneration, only a "rational, scientific" study of nature-a secular, republican natural history-could provide new intellectual weapons with which to combat religious dogma and superstition, both of which were often perceived as the deeply held mainstays of conservative forces.

16. Ernst Haeckel, Las maravillas de la vida: Estudios de Filosofía biológica para servir de complemento a Los enigmas del Universo (Madrid: F. Sempere y Cia, [n.d.]), v-x.

17. Girón Sierra, Evolucionismo y anarquismo (ref. 10), 52.

I8. Haeckel, Las maravillas (ref. I6). F. Sempere also published translations into Spanish of Büchner, Darwin, Reclus, Kropotkin, d'Holbach, Draper, and Engels, among others. See also Ernst Haeckel, Estado actual de nuestros conocimientos sobre el origen del hombre: El monismo, lazo entre la religión y la ciencia (profesión de fe de un naturalista) (Barcelona: Atlante [1905?]). See also Rafael Pérez de la Dehesa, "La Editorial Sempere en Hispanoamérica y España," Revista Iberoamericana: Órgano del Instituto Internacional de Literatura Iberoamericana 35 (I969): 55I-55. 19. Perhaps with the exception of Santiago Ramón y Cajal (1852-1934), who was awarded the Nobel Prize for Medicine in 1906. See José María López Piñero, Cajal (Madrid: Debate, 200o).

20. On the "polémica," see Agustí Nieto-Galan, "The Images of Science in Modern Spain: Rethinking the "Polémica', in The Sciences in the European Periphery during the Enlightenment, ed. Kostas Gavroglu (Dordrecht, Neth.: Kluwer, 1998), 65-86.

2I. Casado, Naturaleza patria (ref. 6), 48. 
In the same way that evolutionary thought should be approached by historians as a complex concept that was continuously renegotiated by actors who were themselves in different cultural contexts, Spanish republicanism is not easy to delineate. ${ }^{22}$ It had its roots in the French Revolution, but also in the more updated values of the third French Republic; that is, in the struggle for democratic access to a secular education and for real influence upon cultural elites with regard to the leadership of the nation. Spanish republicans ranged from those holding moderate, pragmatic positions and willing to take part in the parliamentary rules of the monarchy, to more radical positions that borrowed ideas from anarchism, socialism, and masonry. ${ }^{23}$ Nevertheless, in spite of such fragmentation, the republicans shared a certain ethos based on anticlerical freethinking and uncritical trust in positive science and evolutionary thought, the latter being at the core of their political discourse. ${ }^{24}$ In their view, it was this rational study of nature that could provide useful ideas for the improvement of society, as well as a sort of moral refuge in times of national decline and social instability. ${ }^{25}$ To those subscribing to a more radical position, a positive natural history and its habits and practices had the potential to erase the Catholic religion from the citizen's mind. ${ }^{26}$

In that locally contingent science-religion polarization, natural history, or at least a particular appropriation of natural history-which was at the core of de Buen's political and intellectual agenda-played an important role. It provoked important tensions_-such as the 1895 scandal in Barcelona-within university walls, but then almost immediately spread beyond academic circles and out into specific segments of general society, in which political and scientific agendas intimately merged. That kind of natural history should therefore be taken into account when analyzing its complex transformation into the new

22. Girón Sierra, En la mesa con Darwin (ref. Io).

23. Angel Duarte and Pere Gabriel, "Una sola cultura política republicana ochocentista en España?," Ayer 39 (2000): II-35.

24. J. R. Moore, "Deconstructing Darwinism: The Politics of Evolution in the I86os," Journal of the History of Biology 24, no. 3 (199I): 353-408; Girón Sierra, En la mesa con Darwin (ref. IO); Álvaro Girón Sierra, "Del Anarquismo al librepensamiento: Una propuesta de aproximación al proceso de apropiación del Darwinismo en la Cataluña de finales del siglo XIX," Actes d'Història de la Ciencia i de la Tècnica 3, no. 2 (20IO): II9-29; Manuel Suárez Cortina, ed., La Restauración, entre el liberalismo y la democracia (Madrid: Alianza, 1997).

25. Casado, Naturaleza Patria (ref. 6).

26. Pedro F. Álvarez Lázaro, Masonería y librepensamiento en la España de la Restauración (aproximación histórica) (Madrid: OPCM, I985), I39. 
biology of the early twentieth century, which historians agree still remains poorly understood. ${ }^{27}$

As Robert Richards emphasized in his historiography of biology as one of the nineteenth-century sciences, from the old university classrooms and static collections of the nineteenth century to the new experimental biology in the labs, there were obviously numerous intermediate territories, which provide interesting data for our overall understanding of the subtle and not always linear transformation of the natural sciences. ${ }^{28}$ In a similar vein, Lynn K. Nyhart's book has amended the standard account on late-nineteenth-century German biology based exclusively on academic actors. Nyhart gives voice to different groups of amateurs in civic settings such as museums, schools, and zoos, who developed a more populist natural history that reinforced a new biological perspective of the dynamic integration of animals in nature, contrary to the old, static, taxonomical tradition. ${ }^{29}$ And once in the agora, natural history became a substantial part of the ethics of the polis.

In that context, this paper aims to describe the political load of another populist natural history, beyond the academic circles in Spain at the turn of the nineteenth century. It attempts to add new useful data for further research into these complex idiosyncrasies of natural history. In our case, since de Buen's particular appropriation served specific, well-focused political purposes, it allows us to sketch new intersections between natural sciences and political ideologies, between academic, intellectual programs and political propaganda and proselytism.

Although Odon de Buen's life and work have attracted considerable scholarly interest, not much has been done to place his variety of expository practices in the context of late-nineteenth-century political debates in Spain, specifically with regard to the public culture of republican circles that supported and

27. Lynn K. Nyhart, "Natural History and the 'New' Biology," in Cultures of Natural History, ed. N. Jardine, J. A. Secord, and E. C. Spary (Cambridge: Cambridge University Press, 1996), 426-43. See also Luis Alfredo Baratas, Introducción y desarrollo de la biología experimental en España entre 1868 y 1936 (Madrid: CSIC, I997).

28. See, for example, Richards, "Biology," in Cahan, ed., Natural Philosophy (ref. I2), I6-48.

29. Lynn K. Nyhart, Modern Nature: The Rise of the Biological Perspective in Germany (Chicago: University of Chicago Press, 2009), I-34. I am indebted to Oliver Hochadel for making me aware of this reference. See also Robert E. Kohler, “Labscapes: Naturalizing the Lab," History of Science 40 (2002): 473-50I; Peter M. Harman, The Culture of Nature in Britain (New Haven, CT: Yale University Press, 2009). See also Álvaro Girón Sierra, “The Moral Economy of Nature: Darwinism and the Struggle for Life in Spanish Anarchism (I882-1914)," in Glick, Puig-Samper, and Ruiz, eds., Reception of Darwinism (ref. 3), I89-203. 
spread de Buen's particular concept of natural history. ${ }^{30}$ Herein lies the main aim of this paper.

\section{IN THE UNIVERSITY: BUILDING A REPUBLICAN NATURAL HISTORY}

Several actors and spaces of sociability played a crucial role in de Buen's training as a naturalist in his undergraduate years in Madrid. Multiple visions of nature coexisted at the Sociedad Española de Historia Natural (SEHN), and controversies regarding several aspects of evolutionary thought had been a part of the institution since its founding in $187 \mathrm{I} .{ }^{31}$ In addition, the Museo de Ciencias Naturales provided an arena for debate and the circulation of ideas throughout the nineteenth century. The Museo upheld the Enlightenment tradition of the Real Gabinete de Historia Natural, while at the same time adapting its old, static, diverse collections of dead specimens to new trends in the natural history reform movement, which, especially in zoology, emphasized the study of living animals. ${ }^{32}$ In I90I, after years as university chair, Ignacio Bolivar (I850-1944), one of de Buen's most influential masters, became director of the Museo. He managed to overcome a period of stasis in which much of

30. Although there is no comprehensive approach to de Buen's life and work, several aspects of his scientific production have been studied. See Francesc Bujosa and Thomas Glick, "Odón de Buen y del Clos. Zuera, Aragó, I863-Mèxic, 1945: L'oceanografia,” in Ciència i Tècnica a l'època contemporània als Països Catalans: Una aproximació biogràfica, vol. I, ed. A. Roca Rosell, J. M. Camarasa (Barcelona: Fundació Catalana per a la Recerca, 1995), 76I-9I; Casado, Naturaleza Patria (ref. 6), I5. See also Santos Casado, La escritura de la naturaleza: Antología de naturalistas españoles, I868-I936 (Madrid: Caja Madrid, 2000); Antonio Buj, "Buen, Odón de, Mis memorias (Zuera, I863 - Toulouse, 1939) (Zaragoza: Institución "Fernando el Católico” (CSIC), 2003)," Biblio 3 W, Revista Bibliográfica de Geografía y Ciencias Sociales (Serie documental de Geo Critica) 9, no. 542 (2004); see http://www.ub.edu/geocrit/b3w-542.htm (last accessed on I4 Apr 20I2). J. M. Camarasa and Jesús Ignasi Català, Els nostres naturalistes: En el tercer centenari del naixement de Linné i Bufón, Mètode (Valencia: Universitat de València, 2007); J. M. Camarasa, Cent anys de passió per la natura: Una història de la Institució Catalana d'Història Natural (I899-I999) (Barcelona: Institució Catalana d'Història Natural, 200o); Nieto-Galan, "El llibre de divulgació" (ref. 2). See also de Buen's autobiography: Odón de Buen, Mis memorias (Zuera, I863 - Toulouse, 1939) (Zaragoza: Institución "Fernando el Católico" (CSIC), 2003); Odón de Buen, Síntesis de una vida politica y científica (Zaragoza: Ayuntamiento de Zuera, CSIC, I998). See also Odón de Buen, El concepto de naturaleza, con el retrato del autor y su biografía por $R$. de Pallás (alumno de las facultades de Ciencias y Derecho) (Barcelona: Salvador Manero, I884).

3I. Pelayo, "Repercussion of Evolutionism" (ref. 8), Io9.

32. Oliver Hochadel, "Watching Exotic Animals Next Door: 'Scientific' Observations at the Zoo (ca. I870-19I0)," Science in Context 24, no. 2 (200I): I83-2I4. 
the collections were maintained in the basement of the national library in Madrid and unavailable to the public. ${ }^{33}$ Bolivar was in several aspects a heterodox university professor: he made regular use of insect collections for his entomology classes in the science faculty, and he took his students on scientific trips, for instance to Andalusia and Morocco, a journey that left a deep impression on the young de Buen.

Others also contributed to de Buen's original routes of learning. José Macpherson (I839-1902), the son of a Scottish businessman established in Cádiz and a close friend of Professor Antonio Machado Núnez (I8I2-I896), a committed Darwinist, welcomed de Buen into his private laboratory. The forestry engineer Máximo Laguna (I822-1902) introduced de Buen to the practice of field science. ${ }^{34}$ After a trip through central and southern Spain, de Buen himself contributed to Laguna's Flora Forestal Española, and published a paper in the Anales de la Sociedad Española de Historia Natural, in which he defended botanical geography as a genuine Darwinist science. ${ }^{35}$ That spirit of open, liberal field science was in sharp contrast to the intellectual atmosphere among the science faculty in Madrid, where de Buen often felt constrained by the routine, traditional teaching methods. ${ }^{36}$ As he made clear in his autobiography, theirs was a natural science full of religion, memory, descriptions, and classifications, but without serious study of the functions of reproduction, embryology, genetics, and cell theory. Outside of those university walls, Bolivar,

33. Casado, Naturaleza patria (ref. 6), I79-80.

34. Henrika Kuklik and Robert E. Kohler, eds., Science in the Field, Osiris II (1996). On Maximo Laguna, see Vicente Casals, Los ingenieros de montes en la España contemporánea, I848I936 (Barcelona: Ediciones del Serbal, 1996).

35. De Buen, Mis memorias (ref. 30), 34-45. "Los estudios geográfico-botánicos han adquirido verdadera preponderancia ... recibieron considerable impulso con la aparición de la teoría de Darwin en el horizonte de las ciencias naturales... Combinando entre sí las variaciones que los elementos suelo y clima experimentan en los diferentes países, obtendremos como resultado el carácter de su vegetación.” Odón de Buen, "Apuntes geográfico-botánicos sobre la zona central de la Península Ibérica," Anales de la Sociedad Española de Historia Natural I2 (I883): 42I-40, on 42I-22.

36. Regarding the poor equipment for experimental sciences at the Spanish university, see, for example, Eugenio Mascareñas y Hernández, "Algunas consideraciones generales acerca de las causas que han contribuido principalmente al desarrollo de las ciencias experimentales y de sus aplicaciones en nuestros días," Memorias de la Real Academia de Ciencias y Artes de Barcelona: la Academia, $3^{a}$ época, 4, no. I (I90I). See also Antonio Moreno González, Una Ciencia en cuarentena: sobre la física en la Universidad y otras instituciones académicas desde la Ilustración hasta la crisis finisecular del XIX (Madrid: CSIC, 1989). 
Macpherson, and Laguna soon provided de Buen with more appealing routes of learning. ${ }^{37}$

But de Buen's training as a naturalist cannot be separated from his political education in the city. In spaces of sociability such as informal gatherings (tertulias) in coffee houses, he came into contact with relevant political leaders, and professors such as Salvador Calderón (I853-I9II) who, because of their republican ideas, had been expelled from the university in $1875 .{ }^{38} \mathrm{In}$ those tertulias, de Buen met, among others, Nicolás Salmerón, the aforementioned former president of the first Spanish Republic, and Fernando Lozano (1844-1935), alias "Demófilo," a mason, anticlerical, republican journalist, who together with Ramón Chíes (1846-1893) founded the periodical Las Dominicales del Libre Pensamiento as a counterpoint to the Sunday Catholic mass. ${ }^{39}$ In the same period, and again together with some of his masters, de Buen had already joined a masonic lodge in Madrid. He wrote popular science articles for Las Domincales, and married Lozano's daughter, Rafaela Lozano. ${ }^{40}$

In 1884 , supported by this republican liberal circle, de Buen expressed his sympathy for Haeckel in his master's thesis at the university, and publicly declared himself opposed to any supernatural interpretation of nature:

The beautiful law of evolution ... has made ... for the natural sciences, according to Haeckel's happy expression ... a solid building, founded on the unbreakable basis of demonstrated facts.... The universe is an harmonic set of different beings, different today, but just different phases of the one same matter that has

37. De Buen, Sintesis de una vida (ref. 30), 8.

38. On Calderón see Santos Casado, Quiroga, Carderón, Bolivar: La ciencia en el campo: Naturaleza y regeneracionismo (Madrid: Nivola Tres Cantos, 200I). See also Francisco Giner de los Ríos, La Cuestión universitaria I875: Epistolario de Francisco Giner de los Ríos, Gumersindo de Azcárate, Nicolás Salmerón / introducción, notas e indices por Pablo de Azcárate (Madrid: Tecnos, 1967).

39. Pro-Darwinist scientists regularly published articles in the Republican newspaper La Justicia, which became the organ of public expression of Salmerón's own political party. See Julio Simón Ruescas, "Ciencia, ideología y conflicto político: La polémica evolucionista en España a través del diario republicano La Justicia (1888-I897)," Cuadernos de Historia Contemporánea 2I (1999): 213-25.

40. Pedro F. Álvarez Lázaro, Masonería y librepensamiento en la España de la Restauración (aproximación histórica) (Madrid: Publicaciones de la Universidad Pontificia Comillas, 1985). De Buen's profile as a freemason is described on pp. 139-48. Fernando Lozano Montes, Batallas del libre-pensamiento (por Demófilo) (Barcelona: ETD Micropublicacions, 1994). 
evolved through unlimited time. The supernatural concept of nature is only defended by immature brains, by generations in diapers. ${ }^{41}$

In I886, after his graduation, de Buen was given the opportunity to sail with the navy ship Fragata Blanca on a scientific journey across Europe and Northern Africa. ${ }^{42}$ Under the auspices of Bolivar, who at that time was president of the SEHN, the Ministerio de Fomento had appointed two naturalists to join the expedition and gather new collections for the Museo in Madrid. ${ }^{43}$ De Buen and the forestry engineer Tomás Erice were responsible for equipping the laboratory on board. They traveled to Plymouth, Kristiania (Finland), Stockholm, Saint Petersburg, Berlin, Amsterdam, London, Brighton, and Paris. In each of these cities, de Buen visited natural history museums and botanical and zoological gardens, which he viewed as admirable standards of display to be adapted, if possible, to Spain. After returning to Madrid, the Fragata Blanca set out on the second stage of its expedition, this time to Nice, Algeria, and the Sahara desert. During the journey, de Buen met Hermann Fol (1845-1892) at Villefranche (near Nice). Fol was one of Haeckel's pupils and a very skilled microscopist working on marine biology. ${ }^{44}$ In May I887, the boxes of collected plants, animals, and minerals from the expedition were exhibited at the Ateneo de Madrid, a crucial site for the public debate on evolutionary thought. ${ }^{45}$

Once settled as university chair, first in Barcelona and later in Madrid, de Buen tackled with great commitment a reform of the teaching of natural history. In his view, the discipline needed to be transformed into a new science of practice in the lab and in the field, with microscopes, scalpels, Darwinian evolution, Haeckelian embryos, and a biological chemistry inspired by Claude Bernard (I8I3-I878) and Marcelin Berthelot (I827-1907). ${ }^{46}$ In fact, his passion

4I. De Buen, El concepto de naturaleza (ref. 30), 32-33, on 36: "La preciosa ley de la evolución ... ha hecho ... a las ciencias naturales, según feliz expresión de Haeckel ... un sólido edificio fundado en la inquebrantable base de los hechos demostrados.... El universo es un conjunto armónico de seres, distintos hoy, pero que no son otra cosa que fases diferentes de una misma materia, a través de ilimitado tiempo evolucionada.... El concepto sobrenaturalista de la naturaleza es propio de cerebros aún no desenvueltos y de generaciones en mantillas."

42. Odón de Buen, De Kristiania a Tuggurt (impresiones de viaje) (Madrid: Fontanet, 1887).

43. Alfredo Baratas and Joaquín Fernández, eds., Aproximación histórica a la Real Sociedad Española de Historia Natural (Madrid: Facultades de Biología y Geología , 1998).

44. Bujosa and Glick, "Odón de Buen" (ref. 30), 764.

45. De Buen, El concepto de naturaleza (ref. 30), I2.

46. De Buen, Sintesis de una vida (ref. 30), 7-8. 
for teaching and education at different levels was again intimately embedded in his own political agenda. In a sort of social Lamarckism, inspired by the pedagogical positivism of Herbert Spencer, de Buen defended the effort that every generation made to improve its educational system as a crucial strategy for future progress and social justice. ${ }^{47}$ Therefore, the act of teaching was a central issue in his political agenda, and the school became a crucial space of sociability. ${ }^{48}$

In 1890 , just a year after his appointment as the natural history chair in Barcelona, de Buen published his controversial and later banned Tratado elemental de Zoologia, a volume of his Curso completo de Historia Natural, in which he distanced himself from the traditional use of manuals in the classroom:

A book devoted to the university teaching of zoology ... must provide the student not only with the synthetic picture of that scientific branch; it should awaken in him the genius of observation, get him accustomed to researching nature by putting him in close contact with it; it should help him to solve, on his own, what he would never understand if he were taught dogmatically from a chair turned into a pulpit. ${ }^{49}$

De Buen's students paid additional fees for the maintenance of a natural history laboratory, which included sections for mineralogical analysis, dissected animals, and a projector of images. ${ }^{50}$ In his geology courses, scientific instruments (microscopes and scalpels), chemicals, and fossil collections were closely studied. His textbook on botany contained detailed instructions on preparing samples for the practice of plant anatomy and physiology. ${ }^{51}$ De Buen also traveled regularly with his students—a standard practice in field science. In the

47. I borrow the term from Girón Sierra, En la mesa con Darwin (ref. Io).

48. Manuel Morales Muñoz, "El republicanismo ochocentista: Escuela de ciudadanía," Ayer 45 (2002): 305-19.

49. Odón de Buen, Tratado elemental de Zoología: Curso completo de Historia Natural (Barcelona: La Academia, I890), xxi-xxii: "Un libro dedicado a la enseñanza universitaria de la zoología ... no debe ofrecer sólo al alumno el cuadro sintético de aquella rama científica; es forzoso despertar en él el genio del observador, acostumbrarle a la investigación de la naturaleza poniéndole en contacto con ella, hacer que resuelva por sí lo que no comprendería nunca si dogmáticamente se le enseñara desde la cátedra convertida en púlpito."

50. De Buen, Mis memorias (ref. 30), 56. Some years later, in Madrid, de Buen was also very critical about the working conditions of the science faculty: crowded lecture rooms, lack of experimental facilities, and institutional support, and so on. Ibid., I30-3I.

5I. De Buen, Programa de un curso de Geología, Mineralogía y Botánica, 3rd edn, Curso I89I-92 (Barcelona: Imprenta de Salvador Manero, I89I), II-I2. 
summer of I894, after the establishment of an official collaboration on marine science with Professor Henri Lacaze-Duthiers (I82I-I9OI), de Buen traveled to Banyuls-sur-Mer (southern France) with thirty students to work on marine zoology. In I895, he also made trips to Mallorca and Castelldefels (Barcelona) with more than fifty students, this time with a focus on geology. Later they embarked on journeys to the mountain of Montserrat and the volcanic region of Olot. De Buen's scientific trips covered a good deal of Catalonia, Valencia, the Balearic Islands, southern France, and some parts of Italy, in particular, a visit to Naples to witness an eruption of the Vesuvius volcano. ${ }^{52}$ In formal lectures from his chair, de Buen introduced the main aims of his scientific journeys beforehand, and followed up the trips with a second lecture, complete with collections and photographs. ${ }^{53}$

No doubt, students were at the core of the populist republican interest among the lower classes. They became relevant actors in de Buen's courses and lectures. The syllabus of his courses circulated widely among Spanish academic circles in manuscript, printed versions, together with transcriptions of his oral lessons, natural history leaflets, official programs, and textbooks. ${ }^{54} \mathrm{R}$. de Pallás, one of de Buen's students, wrote a short biography of his master in which he emphasized de Buen's political engagement in freethinking, republican values and the success of his scientific excursions, as a new kind of natural history in the old university. ${ }^{55}$ The new practices of field science were based on scientific trips, but also on positivistic values of empirical observation, informal paths of learning, and fluid relations between teachers and students. Not surprisingly, a good number of students took an active part in defending de Buen's chair after the scandal of 1895 .

De Buen's pedagogical concerns were summarized in an opening address at the University of Barcelona in the academic year 1909-19I0. ${ }^{56}$ Under the influence of the Institución Libre de Enseñaza (ILE) — a secular, freethinking pedagogical movement with strong influence in republican circles-de

52. De Buen, Mis memorias (ref. 30), 56.

53. Since not all students could afford the cost of these trips, the illustrated lectures became useful ways to let them have contact with nature. Ibid., 56 .

54. De Buen, Programa de un curso (ref. 5I), 6-7, and inside cover: "Considerabánse antes los minerales como cuerpos invariables, y se les estudiaba como si siempre hubieran existido bajo la misma forma; los fenómenos de seudo-morfosis y de metamorfismo, prueban que los minerales son seres que se transforman, que se renuevan, que aparecen y desaparecen."

55. El concepto de naturaleza (ref. 30), 6-23.

56. Odón de Buen, Discurso inaugural en la solemne apertura del curso académico de Igog a I9IO ante el Claustro de la Universidad de Barcelona (Barcelona: Tipografía La Academia, 1909). 
Buen again criticized the rote learning system, in which students were little more than phonographs_-reading and repeating empty words. ${ }^{57}$ In 1876 , Nicolás Salmerón was one of the founders of the ILE, together with other professors who had been expelled from the university in 1875 by the new Restoration regime. ${ }^{58}$ Inspired by the ILE pedagogical agenda, which from its onset had included field science and Haeckelian ideas, de Buen promoted a self-experimental method, based on students' own work in the lab and in the field. ${ }^{59}$ Recounting a visit to the laboratory of physical geography at the science faculty of La Sorbonne in Paris, he described the ideal arrangement of a university department in front of his local academic audience, which would include the following: a lecture room; a common room; a room for images, engravings, and photography; a room for experiments; a museum, which had to be constructed by students themselves after their field work; a library; the professor's office; showcases of collections in the corridor; and an office for receiving and sending samples and research materials. ${ }^{60}$

It was only through close contact with nature-in the lab, in the field, through museum collections, at public lectures, and during journeys - that adequate empirical evidence could be gathered for the purpose of settling controversies surrounding the origins and evolution of life on Earth. "Objective," "rational" observations constituted a fundamental part of the positive science that could replace, in de Buen's view, supernatural, religious explanations and in turn reinforce anticlericalism. In light of the marginalization of republican groups during the Restoration, their struggle to counterbalance the official education policies of the regime became fundamental. What, how, and where to teach became basic questions, and natural history provided an ideal setting for answers, which could contribute to the progress of society.

57. Ibid., 9-IO: "los áridos datos ... son lastre que perjudica, impedimento que no deja volar el pensamiento ... siento en la cátedra los efectos desastrosos del sistema que convierte a los estudiantes en fonógrafos, sin las perfecciones de este aparato."

58. For the history of the ILE, see Antonio Jiménez-Landi Martínez, La Institución Libre de Enseñanza y su ambiente (Madrid: Editorial Complutense, 1996).

59. Baratas, Introducción y desarrollo (ref. 27). This self-experimental method included practices such as comparing maps, organizing journeys, relating topographical data with human life, and using images. De Buen, Discurso inaugural (ref. 56), I5.

6o. De Buen, Discurso inaugural (ref. 56), i9. 


\section{AT SCHOOL: TEACHING A RADICAL NATURAL HISTORY}

In the early years of the new century, de Buen's teaching vocation even reached elementary schools. He established a close collaboration with the Escuela Moderna (EM), an educational project of the pedagogue Francesc Ferrer i Guàrdia (I859-1909). ${ }^{61}$ Ferrer, a radical freethinker and anarchist, would eventually be executed in October 1909, having been condemned as an intellectual instigator of the riots in Barcelona earlier that year at the end of July, commonly known as the "Setmana Tràgica" (Tragic Week). ${ }^{62}$ Forced military conscription to fight in the Spanish protectorate of Morocco had provided the catalyst for the unrest. As symbols of political influence and social control, Catholic churches were violently attacked and burned. The repression by the local authorities in response was equally fierce, and Ferrer's execution delivered a serious warning to de Buen's leftist culture. ${ }^{63}$

The EM had been founded some years earlier, in I90I. It was based on values such as freethinking, collaborative learning, secularism, coeducation, and a monistic explanation of the universe. In that context, Haeckel was especially welcomed and relied upon for his strong anti-Christian materialism. As part of his educational crusade, Ferrer had worked with Haeckel in the Ligue Internationale pour l'éducation rationnelle de l'enfance (International League for the Rational Education of Children).

6I. Ferrer's Escuela Moderna has been a continuous object of investigation by scholars. Some other useful works are: Pere Solà, Francesc Ferrer i Guàrdia i l'Escola Moderna (Barcelona: Curial, I978); Buenaventura Delgado, La Escuela Moderna de Ferrer i Guardia (Barcelona: CEAC, I979); Francesc Ferrer i Guàrdia, L'Escola Moderna: Explicació póstuma i abast de l'ensenyament racionalista: Pròleg i notes de Pere Solà (Vic: Eumo, 1990). See also Jordi de Cambra Bassols, Anarquismo y positivismo: El caso Ferrer (Madrid: Centro de Investigaciones Sociológicas, 198I); A. Orts Ramos and F. Caravaca, Francisco Ferrer Guardia, apóstol de la razón (Barcelona: Maucci, 1923). See also Ferrer's own publications and manuscripts available at the Fundació Ferrer i Guàrdia, http://www. ferrerguardia.org/centre-de-documentacio (last accessed on 30 Mar 2012). For Ferrer's own writings see F. Ferrer i Guàrdia, La Escuela Moderna: póstuma explicación y alcance de la enseñanza racionalista (Barcelona: Maucci, [I9I2?]). [http://www.antorcha.net/biblioteca virtual/pedagogica/ escuelamoderna/indice.html] (last accessed on 30 Mar 20I2). See also F. Ferrer i Guàrdia, Principios de moral cientifica (Barcelona: Fundació Ferrer i Guàrdia, 2009).

62. Regarding the influence of anarchist thinking in Catalonia, see Ferran Aisa, La cultura anarquista a Catalunya (Barcelona: Edicions de 1984, 2006). See also José Álvarez Junco, La ideología política del anarquismo español (I868-I9I0) (Madrid: Siglo XXI, 1976); Lázaro, Masonería y librepensamiento (ref. 40).

63. For an overview of the Tragic Week, see Joan Connelly Ullman, The Tragic Week: A Study of Anticlericalism in Spain, I875-19I2 (Cambridge, MA: Harvard University Press, 1974); Bassols, Anarquismo y positivismo (ref. 6I); Pere Voltes Bou, La Semana trágica (Madrid: Espasa Calpe, I995). 
Ferrer soon asked de Buen to participate as a regular collaborator with the school, entrusting him with the writing of a set of pamphlets (cartillas didácticas) entitled Las Ciencias Naturales en la Escuela Moderna and other natural history and geography textbooks. ${ }^{64}$ But de Buen's involvement with Ferrer's project went much further. Together with the physician and professor of the Faculty of Medicine, Andrés Martínez Vargas (I86I-1948), de Buen lectured weekly at the EM, in the Conferencias Dominicales series, on Sundays from II A.M.-noon, plus about twenty minutes for questions. ${ }^{65}$ In a crowded hall filled with children, their parents, and the general public, de Buen covered a wide range of topics: the evolution of nature, minerals, water, geology, botany, the surface of the earth, microscopic observations, animal transformations, cells and species, scientific travels, the atmosphere, physical geography, the bottom of the oceans, and the continents. His own students also attended the Sunday lectures to revisit some contents of the university syllabus. ${ }^{66} \mathrm{In}$ addition, Martínez Vargas lectured regularly on hygiene and pediatrics. Secular hygiene at school, with strict habits enforced among children to avoid contagion, was presented as the opposite of the "Catholic dirtiness" that Ferrer denounced as being commonplace in religious schools.

Although de Buen expressed in public a certain ideological distance from Ferrer's radical program, in practice, both men shared anticlerical, positivistic

64. De Buen, Mis memorias (ref. 30), 96. The pamphlets were titled: Pequeña Historia Natural (I); Pequeña Historia Natural (II); Mineralogía; Rocas y Terrenos; Edades de la Tierra; Estructura de los Vegetales; Vida de los Vegetales; Geografia Física (with a preface by Elisée Reclus).

65. Andrés Martínez Vargas (I86I-I948) is considered a pioneer of pediatrics in the Spanish medical system. He actively contributed to several hygiene campaigns in the city, especially targeting childcare. Among his publications, the most notable are Enfermedades de la infancia: Apuntes de las lecciones explicadas (Barcelona: Tipografía La Publicidad, 1900); Botiquín escolar (Barcelona: Publicaciones de La Escuela Moderna, I905); Tratado de pediatría (Barcelona Tipografía J. Vives. 1915); Historia de la pediatría en España (Madrid: Valera, 1946).

66. Solà, Francesc Ferrer i Guàrdia (ref. 6I), 57-58: "Aún cuando concurría bastante público, éste era bastante heterogéneo y variable, pues se componía de alumnos de la Universidad, discípulos del que declara, que acudían de nuevo a oír explicaciones que ya les tenía hechas, y gentes desconocidas en las que no me fijaba y no puedo por tanto precisarlas; que la asistencia de los alumnos era, a no dudarlo, debida a que en la Escuela se contaba con material moderno y muy perfeccionado, y se hacían proyecciones." On Ferrer's publishing project and its followers, see Pascual Velásquez and Antonio Viñao, "Un programa de Educación Popular: El legado de Ferrer Guardia y la Editorial Publicaciones de la Escuela Moderna (I9OI-I936)," Educació i Història: Revista d'Història de l'Educació I6 (2010): 79-104. I am indebted to Antoni Tort for this information. 
values. ${ }^{67}$ They belonged to the same local freethinking circles, together with such figures as Rafael Rodríguez Méndez (1845-1919), professor of hygiene at the Faculty of Medicine; Joan Giné Partagàs (I836-1903), dean of the Faculty of Medicine; Clemencia Jacquinet, Ferrer's wife and teacher at the EM; Anselmo Lorenzo (I84I-I9I4), a leading anarchist and pedagogue; Eduardo Lozano, professor in the science faculty; Gaspar Sentiñón (I840-1903), an anarchist physician; and Juan Salas Antón (I854-193I), an anarchist writer and follower of Nicolás Salmerón. ${ }^{68}$ De Buen also joined scientific gatherings in Barcelona where he frequently met the pro-Darwinist and histologist Santiago Ramón y Cajal (1852-1934), who received the Nobel Prize for Medicine in 1906.

Drawing on the values of that republican circle, de Buen again defended the idea of prioritizing an empirically active approach to learning about naturewhich itself undergoes continuous renewal and evolution-over an approach based on textbooks and rote memorization. Since he had already applied a good deal of the spirit of "returning to nature" ("volvamos a la naturaleza") in his field science at the university level, he also felt comfortable with the pedagogical project of the EM, which included the material culture of natural history in its collections of minerals, plants and animals, charts, maps, engravings, photos, and films. ${ }^{69}$ In a public lecture on the formation of the Earth's crust, de Buen provided, for instance, detailed explanations of the mechanical, organic, and chemical processes of sedimentation, and used this example to summarily discredit the biblical Genesis in keeping with his anticlerical agenda. ${ }^{70}$

67. "En política no tuve nunca con Ferrer relación alguna." De Buen, Mis memorias (ref. 30), 97. In 1906, the librarian of the Escuela was held responsible for the failed assassination attempt involving a bomb thrown at the Spanish King Alfonso XIII during his wedding procession through the streets of Madrid. Ferrer was arrested and accused of agitating against the monarchy.

68. For details on late-nineteenth-century Spanish anticlericalism, see Julio de la Cueva Merino, "La democracia frailófoba: Democracia liberal y anticlericalismo durante la Restauración," in La Restauración, entre el liberalismo y la democracia, ed. Suárez Cortina, La Restauración (ref. 24), 229-7I. In I900, from his seat in the Barcelona city council, Juan Salas Antón promoted the spread of popular pharmacies in the city. Juan Salas Antón, Proyecto de instalación de farmacias cooperativas ó populares en la ciudad de Barcelona (Barcelona: Imprenta de Ignacio Xalapeira, I900).

69. Odón de Buen, Nociones de Geografia Física (Barcelona: Publicaciones de la Escuela Moderna Maucci, n.d.), II-I2.

70. BEM $_{3}$ (I902): 36: "Esa demostración racional, análoga á la que da la ciencia acerca de todos los fenómenos naturales conocidos y a las hipótesis que sobre los no conocidos aún se forman, destruye por completo la leyenda del milagro genésico, y libra al juicio de supersticiones y a la dignidad humana de imposiciones tiránicas.” 
For that purpose, de Buen published Nociones de Geografía Física, with a translated preface by the French anarchist geographer Élisée Reclus (I8301905). ${ }^{71}$ Funded by Ferrer, as a landmark or symbol of the bibliography of his Escuela, de Buen also reviewed the translation of Reclus's monumental L'homme et la terre. ${ }^{72}$ Under the banner of Reclus, the EM promoted a universal and popular approach to geography by opposing conservative nationalistic readings of that science. In Reclus's view, human civilization was dramatically split into antagonistic social classes, and social injustice inevitably led to revolutions and civil wars. ${ }^{73}$ At the same time, the construction of a free society had to be based primarily on individual efforts toward the construction of a new "social geography," which had to be accessible to the lower classes. ${ }^{74}$ Rejecting textbooks, classrooms, and flat maps, Reclus was against a "scholastic" geography full of descriptions and names, and promoted the close contact of students with real geographical entities and their local particularities. $\mathrm{He}$ further proposed globes as the most appropriate didactic tool to teach students the actual geography of the planet, and included astronomy in that geography.

Inspired by John William Draper, science at the EM was presented as the alternative to religion. ${ }^{75}$ Experiments and observations replaced traditional errors and provided the only reliable guidelines in life, and science, as an "objective" and "uncritical" concept, became the main pillar of Ferrer's teaching project. ${ }^{76}$ In his frequent visits to factories with students, Ferrer presented a positivistic, technophilic image of industry, in which he questioned only the

7I. De Buen, Nociones de Geografia Física (ref. 69).

72. Élisée Reclus, L’homme et la terre (6 vols., Paris: Livrérie universelle, 1905-1908).

73. Ibid., vol. 6, I86: "Les révolutions, sous des formes d'ailleurs fort multiples, sont donc inévitables puisque les evolutions sont contrariées dans leur functionnement normale."

74. De Buen, Mis memorias (ref. 30), 96-97. De Buen described Reclus's approach at the Escuela as follows: "Y se atrevió Ferrer con la publicación en español de la gran obra de Reclus "El hombre y la tierra," recién aparecida en francés, extensa, documentada, pletórica de grabados y mapas. Suponía un enorme esfuerzo económico ... la otra gran obra de E. Reclus, la "Geografía Universal," se publicó en español ... gracias al auxilio del Estado. La traducción de "El hombre y la Tierra" fue confiada a Anselmo Lorenzo ..., pero Ferrer quiso que yo la revisara.”

75. For a recent overview of the science-religion relationship at the end of the nineteenth century, see Ronald L. Numbers, "Creationism, Intelligent Design, and Modern Biology," in Biology and Ideology from Descartes to Dawkins, ed. Denis R. Alexander and Ronald L. Numbers (Chicago: University of Chicago Press, 2010), 302-28.

76. Ferrer i Guàrdia, Escuela Moderna (ref. 6I), I3-I4. For the subtle transformation of anticlericalism into a new kind of religion, see de la Cueva Merino, "La democracia frailófoba" (ref. 68). 
inequalities of its social organization, separate from its science and technology. ${ }^{77}$ Instead of the state, it was civil society-workers' associations, republican societies, popular athenaeums - which needed to take the lead in the utopian project.

In the closing session of the 1903-1904 academic year at the EM, students presented their own radical public statements on the utility of modern science:

The microscope was invented by free men; fanatics are incapable of inventing anything, since they associate everything to God.... Chemistry has helped men greatly. A long time ago, little was known about the nature of gases, and by breathing them many died of asphyxia... physics has provided us with lightning rods that save us from storms.... Hygiene is life. Without hygiene, microbes would control us and we would suffer from continuous epidemics... Thanks to science, not religion, many inventions have been developed up to now. Men began to advance when they abandoned superstitions.... Religion is in inverse ratio to science. ${ }^{78}$

EM students also made extensive use of a peculiar textbook, The Adventures of Nono, written by the French anarchist Jean Grave (1854-1939) and translated into Spanish by Anselmo Lorenzo. ${ }^{79}$ It described the life of a boy, Nono, in an ideal land called "Autonomy," in contrast to the real world of "Argirocracy." De Buen made use of passages from The Adventures of Nono to introduce reflections on animal and social solidarity into his public lectures. Nono suffered physical harassment in an authoritarian school. One night, a fairy invited Nono to travel to a utopian world where girls and boys had equal rights and enjoyed freedom and respect from adults; where values such as solidarity, sincerity, and

77. Anonymous, $\mathrm{BEM}_{3}$ (29 Jun 1904): Io.

78. Ibid.: "El microscopio es un invento de hombres libres, los fanáticos son incapaces de inventar nada porque todo lo achacan a su Dios.... La química ha producido muchos bienes al hombre. Antes se ignoraba lo que eran los gases, y por respirarlos había muertos por asfixia.... La física ... nos ha dado pararrayos que nos libran de las tormentas ... La higiene es la vida. Sin higiene los microbios se apoderarían de nosotros y estaríamos en continua epidemia... Hasta el día se han hecho muchos inventos, debidos a la ciencia, no a la religión. Los hombres empezaron a progresar desde que abandonaron las supersticiones.... La religión está en razón inversa a la ciencia."

79. On Anselmo Lorenzo, see Enric Olivé Serret, "El movimiento anarquista catalán y la masonería en el último tercio del siglo XIX. Anselmo Lorenzo y la logia 'Hijos del trabajo'," in Actas del I Symposium de Metodología Aplicada a la Historia de la Masonería Española, Zaragoza: 20-22 de junio de 1983, ed. José A. Ferrer Benimeli (Zaragoza: Diputación General de Aragón, Departamento de Educación y Cultura, 1985), I33-5I. 
mutual support were common; where education began by stimulating curiosity and observation of the natural world. But then Nono was kidnapped by a millionaire from Argirocracy and brought by force to towns and cities where cruelty and social injustice reigned. The book was discussed in several lectures and also used by workers' organizations as a new kind of primary school textbook in opposition to established values. As readers of Nono, EM students corresponded with other children from popular athenaeums, and their own views were often made public in several articles of the Boletin de la Escuela Moderna (BEM) and at public events.

Interestingly, de Buen's Sunday public lectures at the EM followed the pattern of similar public events in republican associations such as the Círculo Democrático Republicano, Fraternidad Republicana, Centro Republicano Federal, and working-class athenaeums. ${ }^{80}$ Even some years earlier, after the scandal of 1895 in Barcelona, de Buen continued to teach his controversial natural history courses at the Centro Republicano Federal, which acted as a temporary substitute for his closed university classroom and lab. In that context, academic and political institutions played similar roles in terms of the socialization of ideas on nature and society in the public sphere. In fact, as we will see in more detail in the following section, to promote his own political agenda, de Buen's expository practices were not confined to school classrooms and academic settings.

\section{IN THE PUBLIC SPHERE: SPREADING A POPULAR NATURAL HISTORY}

In spite of the lack of luminaries among the science faculties in Spanish universities in the late nineteenth century, popular science books were successful publishing enterprises and were widely read, scientific articles frequently appeared in the daily press, and scientific public lectures were very well attended. Thus, boundaries between research papers, university textbooks, and popular books were not particularly well defined. ${ }^{81}$ It was precisely in this context that

8o. Delgado, Escuela Moderna (ref. 6I), II9.

8I. Faidra Papanelopoulou, Agustí Nieto-Galan, and Enrique Perdiguero, eds., Popularizing Science and Technology in the European Periphery, I800-2000 (Aldershot, U.K.: Ashgate, 2009). See also Terry Shinn and Richard Whitley, eds., Expository Science: Forms and Functions of Popularization (Dordrecht, Neth.: Reidel, 1985). 
de Buen was able to develop his political agenda through the popularization of natural history to a wide audience.

In I89I, de Buen began to work in Barcelona with the publishing house Montaner y Simón on the preparation of four volumes of botany, as part of a thirteen-volume series entitled Historia Natural. ${ }^{82}$ Evolutionary ideas, which had been stated in his early textbooks, also explicitly appeared in those less academic, luxury volumes that targeted Spanish and Latin American bourgeois elites. Further, in reaction to the hostility he suffered in the academic world, especially after the censorship of his textbooks and the temporary closure of his chair in 1895 , de Buen became a tireless popularizer of a Haeckelian natural history. ${ }^{83}$ In 1896, he wrote a new version of his Historia Natural, but this time he addressed it to the lower classes. ${ }^{84}$ It was entitled Historia Natural (edición popular, con profusión de grabados) [popular edition with a rich collection of engravings], in two volumes published by Manuel Soler. The book attempted to overcome the limitations of traditional textbooks in order to reach a wide audience of readers, and was presented as a reply to the unfair attacks leveled against him due to the "damned Catholic intolerance," which, in his view, seriously crippled Spain's progress and prosperity. ${ }^{85}$ De Buen provided detailed, picturesque descriptions of all subjects with hundreds of illustrations, engravings, and maps. His reasons for the new genre were quite clear:

I have quickly published this popular version, on which I have been working for a long time, as a response to the vehement demands from the public who wanted to discover my work that had been censored by the Church. My aim was to spread positive science to the heart of the people ... I hope that this popular

82. Odón de Buen, Historia natural: Novísima edición profusamente ilustrada: Botánica: Con inclusión de la geografía botánica, vol. 8 (I3 vols.; Barcelona: Montaner y Simón, I89I-95). The thirteen volumes are I: Antropología, P. Topinard; 2-7: Zoología, C. Claus; 8-II: Botánica y Geografía Botánica, Odón de Buen; I2: Mineralogía, Gustavo Tschermak; I3: Geología, Archibaldo Geikie. The sales figures ranged from ten to twenty thousand copies, compared to sales of thirty thousand for Historia general del Arte and four hundred thousand for the Diccionario Enciclopédico Hispano Americano. See Fons Borràs: Montaner y Simón, Box II (Barcelona: Biblioteca de Catalunya, 1902). See Nieto-Galan, "El llibre de divulgació” (ref. 2).

83. In a late edition of his popular version of Historia Natural, de Buen divided the volume into the following chapters: Natural Beings; The Soil We Walk On; The Earth on Which We Live; Plants; Animals; The Sea, the Main Center of Life; The Microscope. Odón de Buen, Historia Natural (nociones prelimianares) (Barcelona: Sucesores de Manuel Soler, ca. 1903).

84. Odón de Buen, Historia Natural (edición popular, con profusión de grabados) (2 vols., Barcelona: Manuel Soler, I896).

85. De Buen, Mis memorias (ref. 30), 65. 
edition will contribute to awakening in our people interest in the natural sciences, inspired by the unitary and evolutionary doctrines. ${ }^{86}$

This intention was at the center of the Manuales Soler project, a series of popular books spanning all fields of knowledge addressed to the general reader, but with an important emphasis on the natural sciences. Not by chance, some of de Buen's most relevant masters contributed to the collection. Macpherson wrote one of the volumes of the series on geology, and Calderón contributed to the series on mineralogy, with other Spanish university professors covering other natural sciences. The series was addressed "to fans of education; to men of science, politicians, professionals, as well as individuals who cultivate their intelligence in the arts, the sciences, industries and practical applications; to families wanting to awaken in their homes the love of learning; to scientific, political, professional, and leisure centers and associations, for the intellectual improvement of their members." ${ }^{7}$

De Buen continued to pursue the popular approach by writing the threevolume, highly illustrated Las Ciencias naturales en la época moderna with Maucci, an Italian publisher that specialized in selling cheap popular books and pamphlets in Barcelona. ${ }^{88}$ In his Historia Natural (nociones preliminaries), also edited by Manuel Soler, he expressed the dynamics of our planet in an

86. De Buen, Historia Natural (ref. 84), xvii, xxiii: "He publicado rápidamente esta edición popular, que hacía mucho tiempo preparaba, respondiendo al vehemente apremio de la opinión pública deseosa de conocer la obra anatemizada por la Iglesia, y a mis propósitos, que pongo siempre por encima de todo, de hacer llegar la ciencia positiva al corazón del pueblo. ... Tengo la esperanza de que esta edición popular contribuirá a despertar en nuestro pueblo la afición a las ciencias naturales inspiradas en la doctrina unitaria y evolutiva." (My emphasis). In fact, the book was widely circulated in Latin America. In de Buen's words: "Aún circulan por los países de habla española los dos volúmenes con elegante cubierta roja de mi Historia Natural Popular, fruto bien saneado de los injustos ataques de que me hizo objeto la maldita intolerancia católica (no digo religiosa) que tanto daño hace al progreso y prosperidad de España.” De Buen, Mis memorias (ref. 30), 92 (emphasis added).

87. De Buen, Historia Natural (ref. 84), back cover page: "Las personas amantes de la instrucción; los hombres de ciencia, los políticos, los profesionales, así como los particulares que cultivan su inteligencia en las Artes, Ciencias, industrias y aplicaciones prácticas; las familias que se preocupan de despertar en el hogar la afición al estudio; los centros y asociaciones de carácter científico, político, profesional o recreativo para el perfeccionamiento intelectual de sus asociados; las personas que se preocupan de instruirse en provecho de su propia cultura y de la de sus familias."

88. Odón de Buen, Las Ciencias Naturales en la Época Moderna: por Odón de Buén, Doctor en Ciencias Naturales y Catedrático de las asignaturas de Historia Natural de la Universidad de Barcelona: Pequeña Historia Natural: Primera parte (Geología y Botánica) (5 vols., Barcelona: Maucci [ca. I9I3]). The five volumes are Geología y Botánica; Zoología; Mineralogia; Petrografía; Edades de la Tierra. 
elegant but simple literary style: "The world has gone through different ages: it had its youth, it will reach its old age. It will lose the air that surrounds it, the vegetation that embellishes it, the beings that give it life. It is a natural being that was born, is transforming and will later decompose." 89

De Buen was also involved in other popularizing projects. In 1903, he began to write "Folletín mensual de divulgación científica," a monthly section on science in the newspaper El Liberal. ${ }^{90} \mathrm{He}$ also contributed popular articles to the scientific periodical El Mundo Cientifico, to the popular-science weekly Ciencia popular, and to very cheap, simple, and easily available popular science books published by Maucci. ${ }^{91}$ In addition, a selected number of notable finalyear students accompanied de Buen on his Extensión Universitaria project, which was run by a group of professors who traveled across Catalonia giving regular lectures to cultural societies and workers' organizations. ${ }^{92}$

From his academic publications (university textbooks and research papers) to his popular books, de Buen drew upon an extraordinarily wide range of literary accounts on natural history. Montaner y Simón sold luxury and prestigious encyclopedias in Spain and Latin America, whereas Soler and Maucci invested in a more local, popular, cheaper science. Maucci followed the spirit

89. De Buen, Historia Natural (ref. 84), 31: "El Globo ha pasado por edades diferentes: tuvo su juventud, alcanzará su vejez, perderá el aire que le rodea, la vegetación que le embellece, los seres que le animan. Es un ser natural que nació, se transforma y descompondrá."

90. De Buen, Mis memorias (ref. 30), 93.

91. El Mundo Científico: Periódico resumen de adelantos científicos y conocimientos útiles aplicables a las artes, a la industria y a la agricultura. From 1899 onwards, it was published twice a month. Ciencia popular (Barcelona: Feliu \& Susana, 1906-1907). As a result de Buen published Las Ciencias naturales (ref. 88).

92. For other European examples of the University Extension movement, see Klaus Taschwer, "People's Universities in a Former Metropolis: Interfaces between the Social and Spatial Organization of Popular Adult Education in Vienna, 1890-1930," in Intellectuals, Activists and Reformers: Studies of Cultural, Social and Educational Reform Movements in Europe, 1890-1930, ed. B. J. Hake and T. Steele (Leeds: Leeds Studies in Continuing Education, 1997), 175-202. De Buen, Mis memorias (ref. 30), 6o. De Buen was also involved in the project of a natural science museum in Barcelona, which he wanted to make accessible to all social classes. To that end, de Buen defended the convenience of labeling the garden plants, in order to spread knowledge about them among the popular classes. [Anonymous and untitled article], La Vanguardia, 6 Jul I899, p. 3: "Sobre la conveniencia de rotular las principales plantas del parquet, a fin de difundir sus conocimientos entre las clases populares y proceder en principio a la creación de un jardín botánico, en el cual figuren las más notables plantas exóticas, las medicinales y las de aplicación industrial que se producen y cultivan en nuestra región y en la zona balear." De Buen wanted to appropriate the idea of a public museum issued from some university collections in France (Lille, Lyons, etc.) as a complement to the university extension movement. See De Buen, Discurso inaugural (ref. 56), 20. 
of La Academia, the publishing house of de Buen's early textbooks, which meaningfully was sponsored by Francesc Pi i Margall (I82I-I9OI), another former president of the first Spanish Republic, and directed by Rafael Farga Pellicer (I844-I890), responsible for introducing Bakunin's anarchist ideas into Spain. Not by chance, Manuel Soler had also worked at La Academia before establishing himself as an independent publisher. ${ }^{93}$

In the I9Ios, a public debate on the uses of popular-science books broke out in Barcelona. A group of reputable intellectuals encouraged politicians to invest in basic research, rather than in the popularization of science, as the only way for the country to move forward scientifically. ${ }^{94}$ However, other influential persons defended science popularization as a fundamental requirement for the stimulus of the population. The dilemma was mainly centered on popular science versus expert, academic science, and on the reading of popular-science books versus the reading of updated academic texts. The Catalan intellectual Eugeni d'Ors (I882-I954) was an example of those expressing support for expert professional science:

Today in Barcelona, very few books are needed to complete the catalogue of a popular library.... However, we have a tragic lack of books for people wanting to undertake specialized studies, people who want to study science, high science, real science-discoveries, theories, hypotheses, inventions — as done in the civilized world, but that we are still unable to do. Original science will, in the near future, become the wealth, welfare and emancipation of the country. ${ }^{95}$

In opposition to the argument of d'Ors, de Buen promoted an ambitious science popularization campaign. As had been the case among local popularizers of astronomy, he defended popular science and popular natural history in particular, as a first step toward the subsequent achievement of a critical mass

93. De Buen, Mis memorias (ref. 30), 59.

94. [Anonymous], La Cataluña, 24 Sep i9ıo, 604.

95. Ibid., 603: "Poquísimos libros de los que pueden constituir el catálogo de una biblioteca popular faltan hoy en Barcelona.... En cambio, los que trágicamente hacen falta ... son los libros necesarios al trabajador científico, al que hace estudios especiales, al que quiere hacer ciencia, alta ciencia, ciencia propiamente dicha-descubrimiento, teoría, hipótesis, invención—como se hace en todo le mundo civilizado y como no podemos hacer todavía nosotros. Ciencia original, que mañana deviene para los pueblos riqueza, bienestar, emancipación.” Quoted also in Nieto-Galan, "Not Fundamental in a State of Full Civilization: The Sociedad Astronómica de Barcelona (I9IO-I92I) and Its Popularization Programme," Annals of Science 66, no. 4 (2009): $497-528$. 
of professional scientists in the country. ${ }^{96} \mathrm{He}$ was convinced that many books were needed to popularize the positive sciences and to eliminate concerns, superstition, and fanaticism, which in his view were the essential causes of the moral and material backwardness of the country. ${ }^{97}$ In that sense, de Buen's natural history popular works can be understood as a reaction not only to the Catholic intolerance after 1895, but also to the weakness of the Spanish scientific culture at the end of the century. In its popular version, natural history served as a strategy to spread scientific values in a purportedly backward society; it was used as an excellent example of the value of popular knowledge as a necessary precondition to raise the scientific culture of the nation.

In 1908, in his address to the Société française de zoologie (SFZ), de Buen presented his main reasons for popularizing natural history:

Spreading, propagating, popularizing the study of nature is an immense social contribution; it prepares the atmosphere, and provides a favorable milieu for scientific progress.... We are missing the setting, but we will create it. If at the beginning we cannot contribute to the progress of science with great discoveries, we will prepare at least a legion of selfless workers. ${ }^{98}$

Again, under Haeckel's influence, de Buen defined himself, in line with his political agenda, as a propagandista popular. ${ }^{99}$ It was precisely the backward

96. Nieto-Galan, "Not Fundamental" (ref. 95), 497-528.

97. Odón de Buen, Tratado elemental de Geología ... con diez láminas fototipográficas y numerosos grabados en el texto (Barcelona: La Academia, I890), xvi: "hacen falta en nuestro pueblo muchos libros que popularicen las ciencias positivas para arrancarle las preocupaciones, la superstición y el fanatismo, causas primordiales de su atraso moral y material."

98. De Buen, Mis memorias (ref. 30), 193: "Divulgar, propagar, popularizar el estudio de la Naturaleza es hacer una obra social de inmensa importancia; es al mismo tiempo preparar la atmósfera, disponer un medio favorable a los progresos científicos.... Falta el ambiente: nosotros lo formaremos. Y si desde el primer momento no podemos contribuir al progreso de la ciencia con grandes descubrimientos, prepararemos legión de trabajadores desinteresados."

99. "Beings derive from each other" (Haeckel), in Odón de Buen, Las Ciencias naturales (ref. 88), front page. De Buen, Síntesis de una vida (ref. 30), 19-20: "Hay quien piense que mal se compagina la severa misión del profesor con la candente lucha del propagandista popular. Cuando se ha logrado un estado de derecho en que todas las opiniones son respetadas; en que la libertad alumbra con sus vivos resplandores el trabajo, así intelectual como manual; en que la justicia se cumple en todas las manifestaciones de la vida colectiva, y es la virtud una garantía de bienestar ... cuando se da a la ciencia lo que es de la ciencia, y al trabajo lo que es del trabajo; cuando en el cumplimiento de su misión todo hombre es libre, todo individuo dispone de los medios necesarios, sería incorrecto abandonar el elevado sitial de la cátedra y la placidez del laboratorio para salir a la plaza pública a agitar a las muchedumbres con la palabra." (my emphasis). 
situation of Spain — politically and scientifically_compared to Northern European countries that forced an academic professor to conquer the public sphere with popular science. It was a science that provided a rational vision of nature, which—as Santos Casado has recently emphasized—can contribute in times of unrest, social tensions, and uncertainties to a secular rationalization of life. ${ }^{100}$ In the same vein, de Buen's own words from his autobiography are convincing:

[If] we live in a corrupt society, in which freedom is a farce, justice is a legend and virtue is an obstacle, in which fakes and hypocrites are the true stars, and manual and intellectual workers have a miserable life; when there is lack of means for university professors and a lack of bread for school teachers; when ignorance gets what science deserves, and vagrancy more than work ... men of science have to spread truth to the people to awake from their lethargy and conquer their moral dignity and material welfare. ${ }^{101}$

In a context in which the natural sciences enjoyed all the virtues of knowledge and almost no criticism-recall, for example, Ferrer's deification of modern science at the EM-those men of science had taken on the utopian mission to spread a new truth to the people, to diffuse a real, objective knowledge about nature, which could both replace religion and empower the lower classes with strong moral and ideological arguments to free them from the hegemonic control of the elites of the monarchy.

\section{CONCLUSION: NATURAL HISTORY FOR THE REPUBLICAN NATION}

After the 1898 crisis, public controversies regarding the causes of the nation's backwardness took multiple forms and expressions. As already mentioned in this paper, the struggle for life that occurred in nature could be argued as a legitimization for the fierce competition among nations in Europe and in colonial territories, for economic, political, and cultural leadership. In line with

Ioo. Casado, Naturaleza patria (ref. 6), 329.

IOI. De Buen, Sintesis de una vida (ref. 30), 20: "si se vive en una sociedad corrompida, en que la libertad es una farsa, la justicia un mito y la virtud un estorbo; en que son personajes el farsante y el hipócrita, y arrastran vida miserable el obrero de la inteligencia y el obrero manual; cuando falta al profesor en su cátedra medios de trabajo, y al maestro en su hogar pan para alimentarse; cuando se da a la ignorancia lo que debe darse a la ciencia, y a la vagancia lo que pertenece al trabajo ... los hombres de ciencia ... [deben] hacer llegar la verdad a los pueblos para que despierten de su letargo y conquisten su dignidad moral y su bienestar material." (my emphasis). 
Spencer's analogy between laws of transformation of organisms and laws of the history of society, Spanish military and scientific defeats were explained through the superiority of Anglo-Saxon nations (the United States among them), which had to be counterbalanced in republican circles by a new Iberian, Latin rearmament in Southern Europe. ${ }^{102}$

In times of decline and collective pessimism, de Buen's natural history played an important role in the politics of the making of the nation. Although nationalism was a controversial issue among republican groups, especially due to their confrontation with federalists, that is to say, defenders of the autonomy of smaller, local entities, prior to the nation-state, de Buen supported a more homogeneous Spanish nationalism. ${ }^{103}$ His rational, scientific approach to nature also fit well with the rational, scientific analysis that regenerationists made about the illness of the nation and its potential recovery. Through new educational projects, they wanted to give a voice to students in a secular atmosphere that could act as a counterweight to the influence of the Catholic Church and its responsibility for the 1898 crisis.

Paradoxically far from radical political positions, however, de Buen never abandoned the more pragmatic strategy of seeking political alliances within the establishment. In the same way that he had distanced himself in public from Ferrer's radical anarchist ideas in order to present a more moderate image of his political positions (we should remember that he wanted to appear in public as a moderate freethinker, only opposing the most right-wing versions of Catholicism), de Buen's nationalism was tinged with a nostalgia for the old Spanish imperialism in Latin America, especially after the 1898 crisis, and the loss of Cuba and the Philippines. Although internationalism, universality, federalism, and cosmopolitan solidarity were commonly subscribed to by liberal freethinkers and anarchists, de Buen was in favor of Spain's annexation of Portugal and Morocco. His personal friendship with Prince Albert of Monaco and with Archduke Luis Salvador de Habsburg-Lorena (sometimes known as Luis Salvador of Austria) was apparently incompatible with his freethinking, republican ideology, but in practice it became a strategic tool, an alliance between

IO2. Josep Maria Ruiz Simon, "Eugeni d'Ors i l'imperialisme català (1903-1909)," in El pensament d'Eugeni d'Ors, ed. Josep Maria Terricabras (Girona: Documenta Universitària, 20IO), 53-84, on 55-62.

I03. Duarte and Gabriel, "Una sola cultura" (ref. 23), 25-34; de la Cueva Merino, "La democracia frailófoba” (ref. 68). 
knowledge and power that was not uncommon in the political culture of certain Spanish republicans. ${ }^{104}$

In I9IO, de Buen accompanied King Alfonso XIII to the opening ceremony of the Oceanographic Museum in Monaco, which had been founded by de Buen's friend, Prince Albert. In 1908, in his presidential address at the SFZ, de Buen had already drafted what would become the guiding principles of the future Instituto Español de Oceanografía (IEO), aiming to study the physical, chemical, and biological conditions of the sea for the improvement of fishing efficiency and techniques in Spain. De Buen conceived of the IEO as "the university of the sea," projecting the new endeavor to take on some of the challenging problems he could not handle properly in a more traditional academic setting. ${ }^{105}$ In 1919, he joined, for instance, the International Commission for the Scientific Exploration of the Mediterranean Sea, the International Union of Geophysics and Geodesy, the International Council for the Exploration of the Sea, and the Latin American Oceanographic Council. In 1929, during one of the public events of the Seville International Exhibition, de Buen chaired the first International Conference of Oceanography. ${ }^{106} \mathrm{He}$ used the new science of the sea to involve the backward nation in the international network of science, and also to place science on the agenda of the foreign office of the monarchy.

This cosmopolitanism and internationalism, with elements of imperialism, were values and targets that helped de Buen to reconcile his ideals with the monarchic, conservative elites. It reinforced the need to build new, foreign contacts, to overcome Spain's traditional scientific backwardness, and to find a decent place for the nation in the emerging republic of letters of the new

IO4. De Buen translated Louis Joubin's work on the metamorphosis of marine animals. Joubin was a close collaborator of Prince Albert of Monaco. In I9I2, the latter lectured in Madrid in front of the royal family to publicly endorse the creation of an institute of oceanography in Spain. Odón de Buen, Trabajos de Oceanografia (Madrid: IEO, I9I6), xxvii.

I05. Bujosa and Glick, "Odón de Buen" (ref. 30), 778. In a similar vein, in I916, Josep Maluquer, the Secretary of the Municipal Natural Sciences Board in Barcelona, described oceanography as the "natural history of the sea" and as the "science of the sea," which studied all the natural phenomena-physical, chemical, mechanical, and biological—that took place in the sea. "Oceanografia: ciència del mar; és la branca del grup de les naturals que estudia els diferents fenòmens que s'esdevenen en les aigües i costes que les circunden, tant sots l'aspecte físic i químic, com sots el mecànic i biològic, és a dir, la història natural del mar en son sentit més ampli.” Joseph Maluquer, Oceanografia (series titled: Minerva: Col.lecció popular de coneixements indispensables) (Barcelona: Bonavia, Duran [19ı6?], 5 .

Io6. Buj, "Buen, Odón de" (ref. 30), 5-6. 
century. ${ }^{107}$ De Buen's true founding of the new science of oceanography obviously can be debated by historians, but its political appropriation seems indisputable. ${ }^{108}$

In I889, the International Congress of Freethinkers at the Paris Exhibition was attended by such luminaries as Herbert Spencer and the French chemist Marcelin Berthelot, but also by Salmerón, de Buen, and Clemencia Royer, a translator of Darwin into Spanish. Including quotes from Voltaire, Diderot, and Victor Hugo, among other French celebrities, the proceedings of the meeting also contained far-reaching conclusions: "Universal morality borrows its materials from anatomy, physiology, embryology and sociology ... morality in its essence should be built on the basis of naturalism." ${ }^{109}$ Those conclusions strengthened the moral authority of nature, linking it to specific political purposes such as the advancement of freethinking and anticlericalism, which were elements of the core agenda of Spanish republicans. Such rhetoric also portrayed the reform movements that had broadened the study of the three kingdoms of nature beyond the confines of academia to include museums, scientific trips, zoological parks, and scientific and civic societies. It was a science that presented life in continuous evolution, in the context of progress in nature and society, and a science that rejected inherited dogmas and superstition and appeared to embrace a kind of scientism. In spite of its marginalization from the mechanisms of monarchical power, it aimed to build an objective method of studying nature to replace religious beliefs and practices among the popular classes.

Nevertheless, also in I889-the year of the centenary of the French Revolution that had greatly inspired the liberal republican tradition-the first Spanish Catholic Congress took place in Madrid, a deliberate reaction to freethinking and evolutionary thought, but also an implicit acknowledgment of the influence of republicanism - in spite of its divisions and wide range of ideological positions-in Spanish society. ${ }^{110}$ In that context, de Buen's ambitious popularizing campaign can be partly understood as an intrinsic aspect of his positivistic duty, but also as a bitter reaction against the attack on his academic freedom

I07. Casado, Naturaleza patria (ref. 6), 49-53.

I08. Bujosa and Glick, "Odón de Buen" (ref. 30), 76I-9I.

I09. "La moral universal toma sus materiales de la anatomía, de la fisiología, la embriología y la sociología ... la moral en su esencia debe construirse sobre las bases del naturalismo," Lázaro, Masonería (ref. 40), 264. See also Lorraine Daston and Fernando Vidal, eds., The Moral Authority of Nature (Chicago: University Chicago Press, 2004).

IIO. Duarte and Gabriel, "Una sola cultura" (ref. 23), 22. 
in 1895 , and as a dissemination of his republican program through university extension itinerant talks, Sunday lectures at the EM, and his intimate relationship with republican clubs, associations, and political parties. ${ }^{111}$ A Haeckelian natural history, which obviously had to include its ambitious popularization program, aimed to provide new intellectual tools to the lower classes in the fight against religious hegemony. The conquest of the public sphere had, in de Buen's view, important consequences regarding his scientific authority in the university, but also with respect to his political agenda, which paradoxically included pragmatic aspects of republican nationalism with a good dose of Iberian imperialism.

Anticlericalism and nationalism acted as ethos of the republican culture in de Buen's mind. In his view, both needed to be based on empirical, objective, and scientific evidence. Without a doubt, de Buen's natural history provided a dynamic account of life on Earth that stimulated social change and contributed to the struggle for equal opportunities for citizens of the ideal Spanish Republic.

\section{ACKNOWLEDGMENTS}

Preliminary versions of this paper have been presented at three seminars: "La ciència i els seus publics," at the Universitat Autònoma de Barcelona in 2008; the "ThreeSocieties Meeting," in Oxford, July 2008; and the "Host Meeting on Science Popularization," in Lisbon, September 2010. I am indebted to Agustí Camós, Pilar Vélez, Ana Simoes, Robert Fox, and Arne Schirrmacher for useful comments on draft versions of this article. Oliver Hochadel's critical reading of this text has been of great assistance. The critical comments of two anonymous referees were also useful for improving the manuscript. This research has been funded by the Spanish Ministerio de Ciencia y Tecnología HAR2009-12918-C03-02; the research group SGR-2009887, "Science, Technology and Medicine in Modern Catalonia" (eighteenth through twentieth centuries); and the research program, ICREA-Academia 2009. Aspects of this paper have been published in Nieto-Galan,"El llibre de divulgació," in Vélez, ed. L'exaltació (ref. 2), 201-20; and Agustí Nieto-Galan, "The Popularization of Science in Spain around 1900: New Sources, New Questions," in Communicating Science in 20th Century Europe: A Survey on Research and Comparative Perspectives, preprint no. 385, ed. Arne Schirrmacher (Berlin: Max Planck Institute for the History of Science, 2009), 77-92.

III. Annie Petit, "La diffusion des savoirs comme devoir positive," Romantisme, La science pour tous 65 (1989): 7-25. 
Reproduced with permission of the copyright owner. Further reproduction prohibited without permission. 